\title{
MULTIFACTORIAL ANALYSIS OF THE GEOCHEMICAL CHARACTERIZATION IN A BRAZILIAN HYPERSALINE FLOODPLAIN
}

\author{
COSTA, D. F. S. ${ }^{1,3^{*}}$; BARBOSA, J. E. L. ${ }^{2}$; ROCHA, R. M. ${ }^{1}$; SOARES, A. M. V. M.. ${ }^{3}$ \& LILLEB $\varnothing$, A. I. ${ }^{3}$ \\ 1 - Laboratório de Ecologia do Semiárido, Departamento de Geografia, Universidade Federal do Rio \\ Grande do Norte (Campus de Caicó), Brasil. \\ 2 - Laboratório de Ecologia Aquática, Departamento de Biologia, Universidade Estadual da Paraíba \\ (Campus central - Campina Grande), Brasil. \\ 3 - Departamento de Biologia, Centro de Estudos do Ambiente e do Mar - CESAM, Universidade de \\ Aveiro, Portugal. \\ *Corresponding author: diogenesgeo@gmail.com
}

\begin{abstract}
Costa, D. F. S.; Araújo, D. M.; Rocha, R. M.; Soares, A. M. V. M. \& Lillebø, A. I. (2014) Multifactorial analysis of the geochemical characterization in a Brazilian hypersaline floodplain. Braz. J. Aquat. Sci. Technol. 18(1):81-90. elSSN 1983-9057. DOI: 10.14210/bjast.v18n1.p81-90 Hypersaline floodplains (sabkhas or saltflats) consist of the supratidal plains with low input of clastic sediments, high evaporation rates, and crustal salts. These environments are prone to periodical floodings and evaporite deposition, common in coastal areas with flat topography of arid regions, developing in response to two environmental conditions: deflation of surface sediments, or accumulation of sediments in a lake, or by a combination of both processes. This research developed a geochemical and textural characterization in soil samples collected in the estuarine floodplain $\left(367.7 \mathrm{~km}^{2}\right)$ of the Apodi-Mossoró River (Northeastern coast of Brazil), analyzing the results using multivariate statistics. The cluster and PCA analyses applied to the set of sampled sites enabled the identification of two zones typical of the estuarine plain, as well as the major groups of parameters related, being one with the greater direct influence of tides (lower estuary) and another, upstream. This is a result of the a gradual accumulation in the soil (mainly sodium), after the flood period in the spring tides, followed by a rapid water evaporation caused by high temperatures $\left(>30^{\circ} \mathrm{C}\right)$ and constant winds.
\end{abstract}

Keywords: Wetland, hypersalinity, geochemistry, semi-arid, Brazil.

\section{INTRODUCTION}

Some of the first studies on hypersaline floodplains took place with the discovery of coastal evaporitic in the Trucial Coast, Persian Gulf (Curtis et al. 1963) current territory of the United Arab Emirates. These supratidal plains consist of areas with low input of clastic sediments, high evaporation rates, and crustal salts, called by the Arabs as "sabkhas" (saltflats in English) (Kendall 1984; Kendall \& Harwood, 1996). These environments are prone to periodical flooding and evaporite deposition, dominated by carbonates or sulfates, may occur in inland and coastal zones, common in coastal areas with flat topography of arid regions, developing in response to two environmental conditions: deflation of surface sediments, or accumulation of sediments in a lake, or by a combination of both processes (Evans, 1970; Al Farraj, 2007).

Since the publication of Curtis et al. (1963), the Trucial Coast, the Qatar Peninsula, and Baja California have become classical areas for studying the formation of evaporites in hypersaline floodplains. These zones achieved a significant economic interest due to this association of sedimentary facies such as algal mats formed on the intertidal zone, nodules and enterolitic structures of calcium sulfate, both gypsum and anhydrite, typical of the supratidal zone, and cubes and skeletal forms of halite in a carbonate or siliciclastic matrix, all evidences for the identification of a sabkha-type marginal environment (Silva et al., 2000), and important for the initiation of oil formation (Al Farraj, 2005).

In Brazil, these environments were described only on the coast of the states of Sergipe and Rio de Janeiro (Silva et al., 2000), but they also occur in large areas of the states of Rio Grande do Norte and Ceará, according to some studies (e.g. Moreira et al., 1989; Mendes et al., 2008) on hypersaline soils (Gleissolos sálicos - Brazil/Solonchaks - FAO) performed in these states. These areas have assumed special importance since the colonization of Brazil, being occupied for the construction of solar saltworks (Vita et al., 2007), mainly due to specific characteristics of this type of soil, such as the high salinity and impermeability (Abro et al., 1988; Kendall \& Harwood, 1996; Guo et al., 2006). These alkaline soils $(\mathrm{pH}>8.0)$ have salt horizon $(1: 1 \mathrm{in}$ water), with $\left(\mathrm{Cl}^{-}\right)>\left(\mathrm{SO}_{4}{ }^{2-}\right)>\left(\mathrm{HCO}_{3}{ }^{-}\right)$, characterized by a sodium saturation (100Na+/CTC) equal to or higher than $15 \%$ (CEC at the saturation stratum equal to or higher than $7 \mathrm{dS} / \mathrm{m}$, at $25^{\circ} \mathrm{C}$ ) in any time of the year, being strictly limited to zones with arid and semi-arid 
climate and coastal regions (EMBRAPA, 1999; FAO, 2006).

This research developed a geochemical and textural characterization in soil samples collected in the estuarine floodplain of the Apodi-Mossoró River (Northeastern coast of Brazil), analyzing the results using multivariate statistics. This strategy has been applied successfully in studies on floodplains (e.g. Gallego et al., 2002; Abílio et al., 2004), where the present data will add valuable information about the characterization of this type of environment in the semi-arid coast of Brazil, since it is already well studied in other countries (e.g. Australia, Uzbekistan, Spain, Mexico, China, etc.) (Ridd \& Stieglitz, 2002; Mees \& Singer, 2006; Álvarez-Rogel et al., 2007; Dendooven et al., 2010; Zhang et al., 2011).

\section{MATERIAL AND METHODS}

\section{Study area}

The flood fluvial-marine zone of the estuary Apodi-Mossoró, located in the Northern coast of Rio Grande do Norte State, Brazil (Figure 1), corresponds to $367.7 \mathrm{~km}^{2}$, subjected to seasonal flood tides up to 3.80 meters. Currently the hypersaline floodplain (sabkha, saltflat, 'deserto salino') has a remnant area with $58.4 \mathrm{~km}^{2}$, since great part of this plain was occupied by the solar saltworks. These supratidal areas have a topographic level higher than infra and mesotidal areas, where are located the mangroves, with flat to slightly sloping surfaces, with altitude from 0 to 2 meters in relation to the level of the estuarine water, only flooded in periods of annual floods (fluvial discharge) and in the spring tides. The origin of this plain is related to the ancient plain areas of estuarine tides, currently subjected to the fluvial-marine dynamics, overflow of the channels during the floods and to the high tides, and that the Cenozoic tectonic deformed area in the form of an anticline which allowed the entry of marine fluvial system into the continent (Maia, 2012) being made up by unconsolidated sandyclayey sediments.

These zones, on the banks of the current beds and/or in the interior in the form of islands, are remnants of (natural) siltation of ancient estuarine plains at higher levels, mainly characterized by alluvial deposits, especially during periods of large floods. Considering

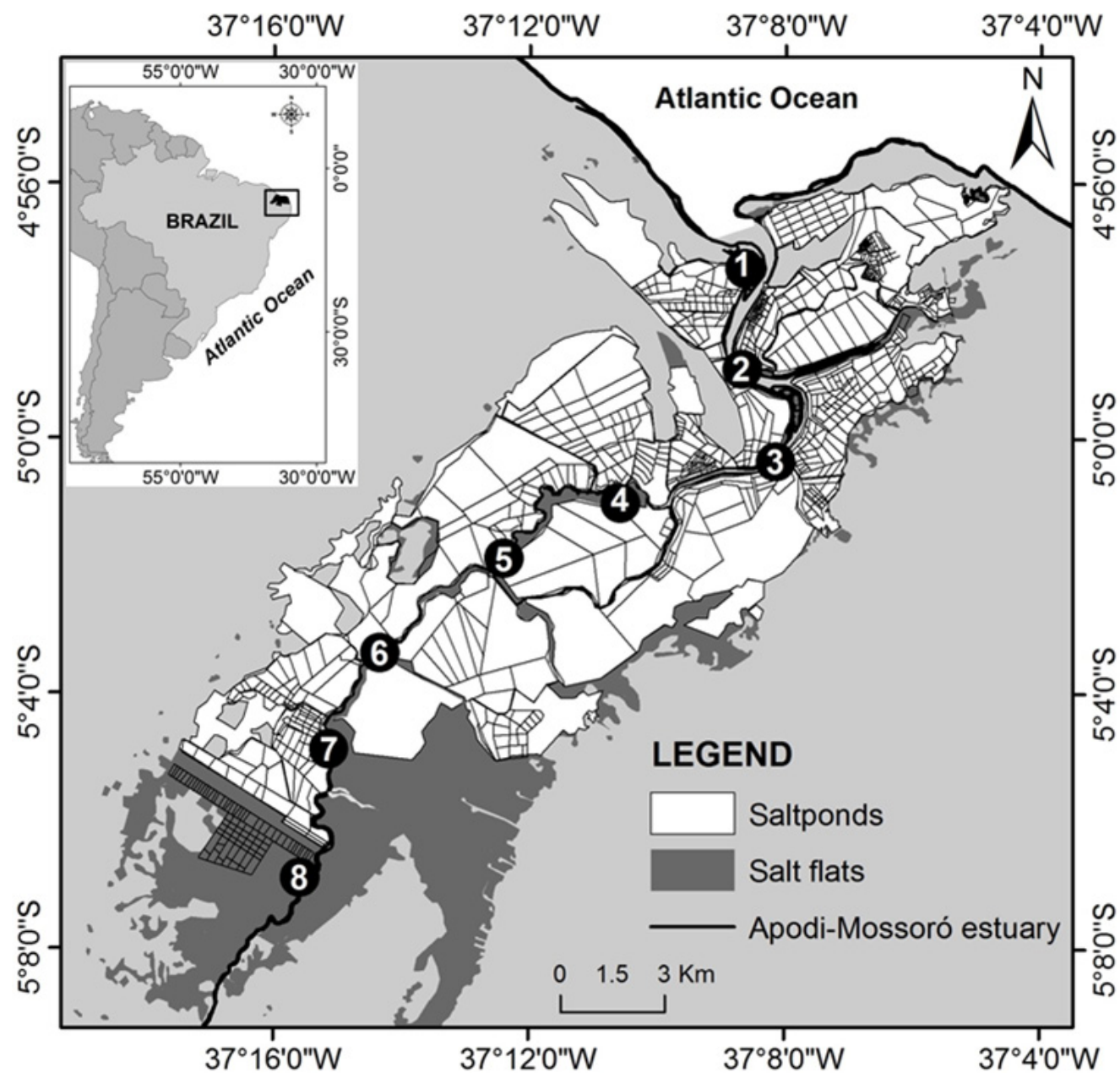

Figure 1 - Location of the sites of soil samplings in the hypersaline floodplain of the estuary Apodi-Mossoró (Rio Grande do Norte State-Brazil). 
the vegetation, only strata of herbaceous halophytes are identified in those areas, once the mangrove vegetation is not found due to the high salt content in the soils (Duke et al., 1998; Lovelock et al., 2009; Costa, 2010). In climatic terms, this zone is situated on the Brazilian semi-arid coast, with high temperatures $\left(>28^{\circ} \mathrm{C}\right)$, low rainfall $(<800 \mathrm{~mm} /$ year $)$ and high evaporation rates (Costa, 2010). Because of these climatic factors for most of the year (dry period - April to December), the estuaries become hypersaline and reach salinity values above 45 ppm (Silva et al., 2009).

\section{Sampling and analysis}

Soil samples were gathered from 08 sites on the estuary banks on February 18th, 2009 (Figure 1 ), whose location was selected according to data of water salinity of Silva et al. (2009). Samplings were conducted during low tide, by random collections of $0.5 \mathrm{~kg}$ on the soil surface $(0-15 \mathrm{~cm})$ to determine the following parameters: macro and micronutrients $\mathrm{CCa}^{2+}$, $\mathrm{Mg}^{2+}, \mathrm{Na}^{+}, \mathrm{K}^{2+}, \mathrm{Fe}^{2+}, \mathrm{Mn}^{2+}, \mathrm{Zn}^{2+}, \mathrm{P}$ and $\mathrm{C}$ ), content of organic matter, sediment, sediment granulometry, Cation Exchange Capacity (CEC), electric conductivity (EC), $\mathrm{pH}$ and temperature, analyzed as described in EMBRAPA (1997). The measures of $\mathrm{pH}$ and temperature were undertaken in situ, using a $\mathrm{pH}$ meter (model $\mathrm{PH}-2500$ ) and digital thermometer (model AL-200C), respectively. The samples were taken to the laboratory, dried at $60^{\circ} \mathrm{C}$ and sieved (nylon mesh $<1 \mathrm{~mm}$ ). After this, the samples were stored in sealed vials in dry environment, conditioned at $20^{\circ} \mathrm{C}$ until analysis.

In relation to the chemical analysis, we also determined: total $\mathrm{C}$ and organic matter by the method of Yoemans and Bremner (1988); macro and micronutrients by $\mathrm{KCl}$ extraction $\left(\mathrm{mol}^{-\mathrm{L}^{-1}}\right.$ ), and atomic absorption spectrophotometric determination. All the analyses were based on the methods described in Embrapa (1997).

In order to analyze the variation in the geochemical parameters it was applied multivariate statistics (Hardle \& Simar, 2007), firstly using a Principal Component Analysis (PCA) on a matrix with all variables analyzed. To identify the spatial distribution of these parameters, a Cluster Analysis was performed, with the Ward linkage method and quadratic Euclidean distance. Also, a Pearson Correlation Coefficient $\left(R^{2}\right)$ was estimated, being the significance level $(p)$ of the mean value examined by the Student's t-test. All statistical analysis were run using the software Statistica v. 8.

\section{RESULTS}

All the samples represented a soil of the type 'Gleissolo sálico' (EMBRAPA, 1999; Solonchaks FAO, 2006), whose values and descriptive statistics of each parameter are listed in Table 1.The $\mathrm{pH}$ of the soil sample analyzed along the estuary Apodi-Mossoró was considered alkaline without significant variation between the sites $\left(t_{7}=0.0449 ; p>0.05 ; R^{2}=0.49\right)$, with values ranging from $8.15(\mathrm{P} 1)$ to $8.58(\mathrm{P} 7)$. Taking into account the hypersaline character of the estuary, high conductivity values were observed, with a significant variation $\left(t_{7}=13.7514 ; p<0.05 ; R^{2}=0.55\right)$. On the lower estuary the CEC varied little, between 97.50 (P3) and $117.00 \mathrm{dS} / \mathrm{m}$ (P1), while on the upper estuary the

Table 1 - Values and descriptive statistics of each parameter analyzed on the banks of the hypersaline estuary of Apodi-Mossoró (Rio Grande do Norte-Brazil): EC - Electric Conductivity; CEC - Cation Exchange Capacity; SNa - Sodium saturation, OM - Organic Matter, $\mathrm{N}$-Number of samples; Med = arithmetic mean; $\mathrm{S}=$ Sum of all values; Min - Minimum value found; Max - Maximum value found; $\mathrm{V}$ Variance; SD - Standard Deviation; CV - Coefficient of Variation; SE - Standard Error of the mean.

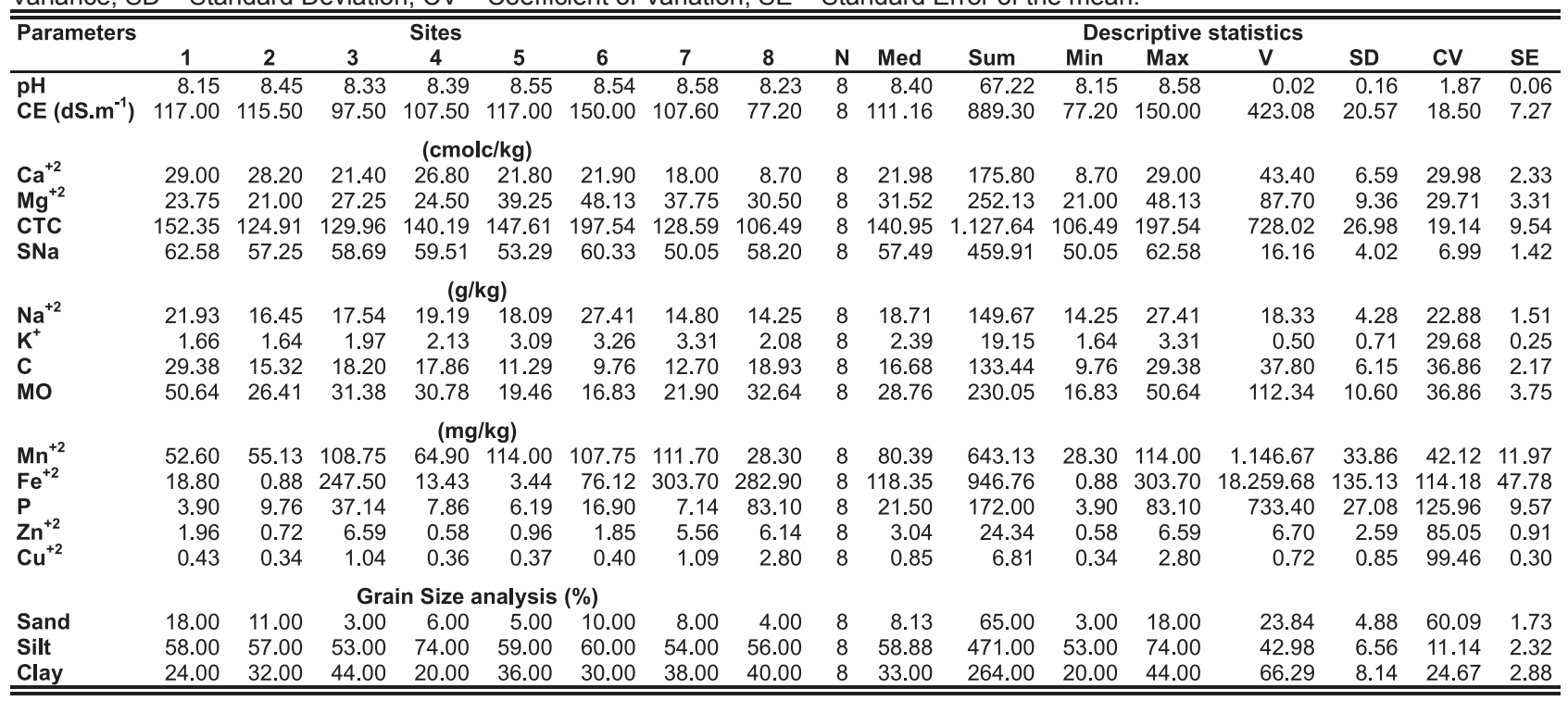




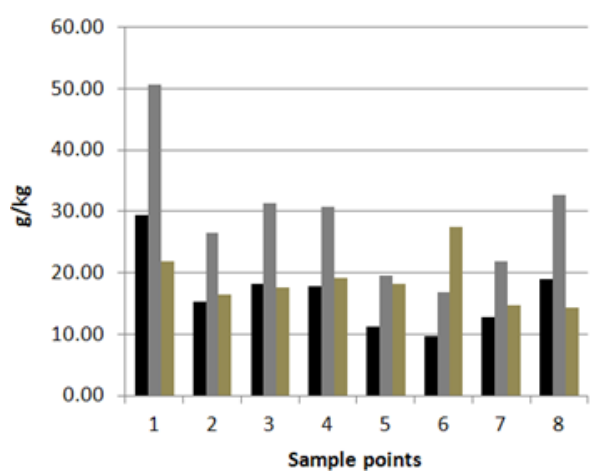

a $C\left(R^{2}=0.3137\right)$

= $O M\left(R^{2}=0.3137\right)$

ENa $\left(R^{2}=0.0519\right)$
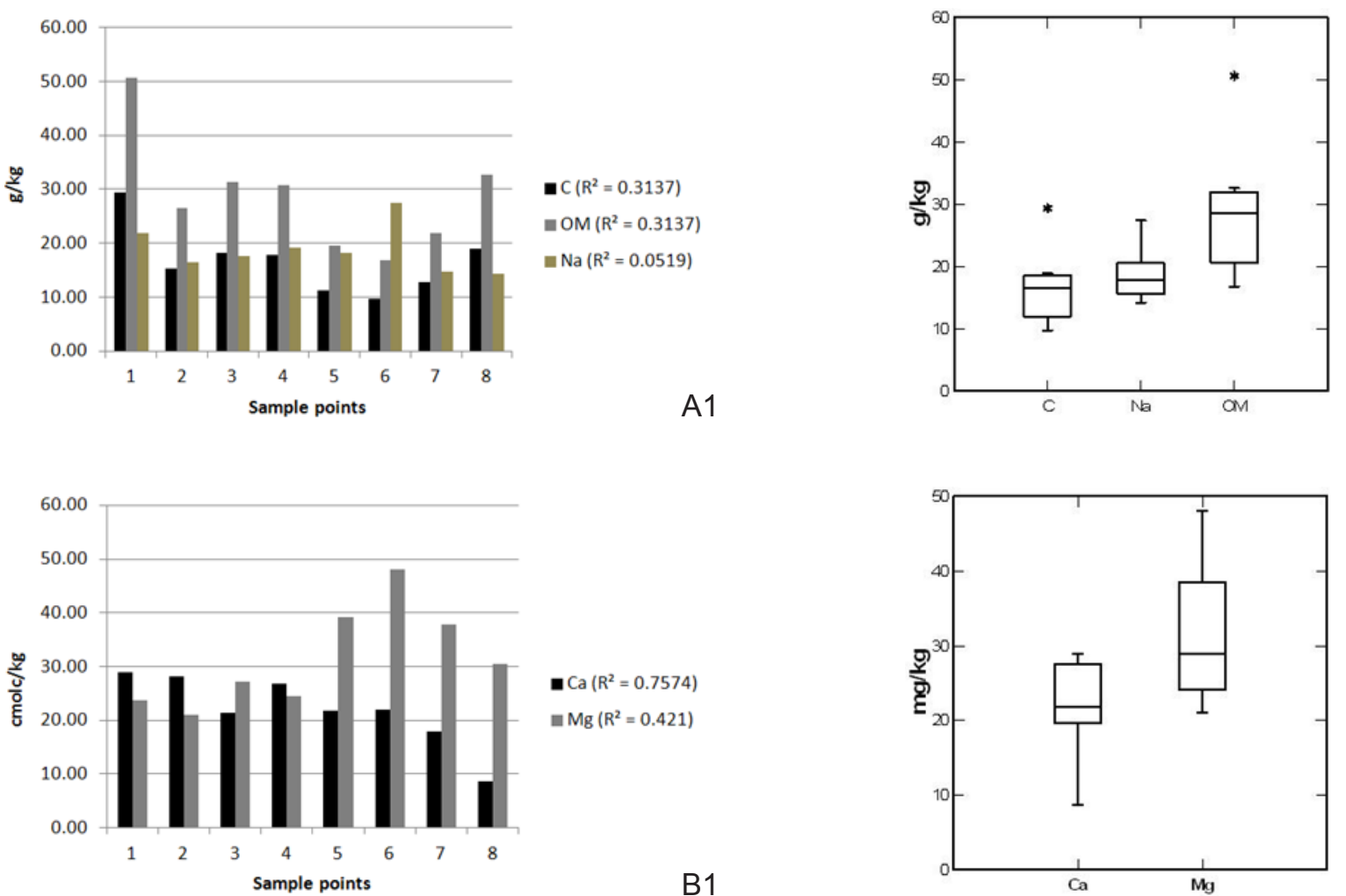

- $\mathrm{Ca}\left(\mathrm{R}^{2}=0.7574\right)$

$\operatorname{Mg}\left(\mathrm{R}^{2}=0.421\right)$

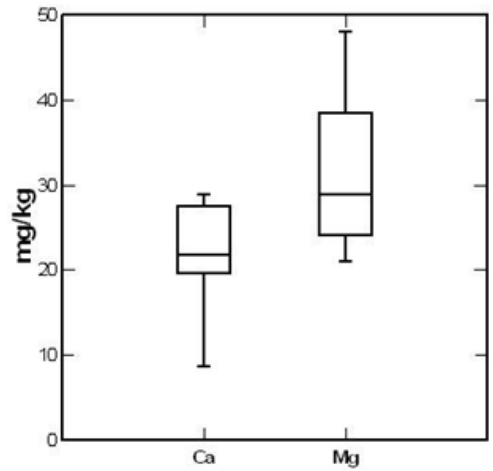

B2
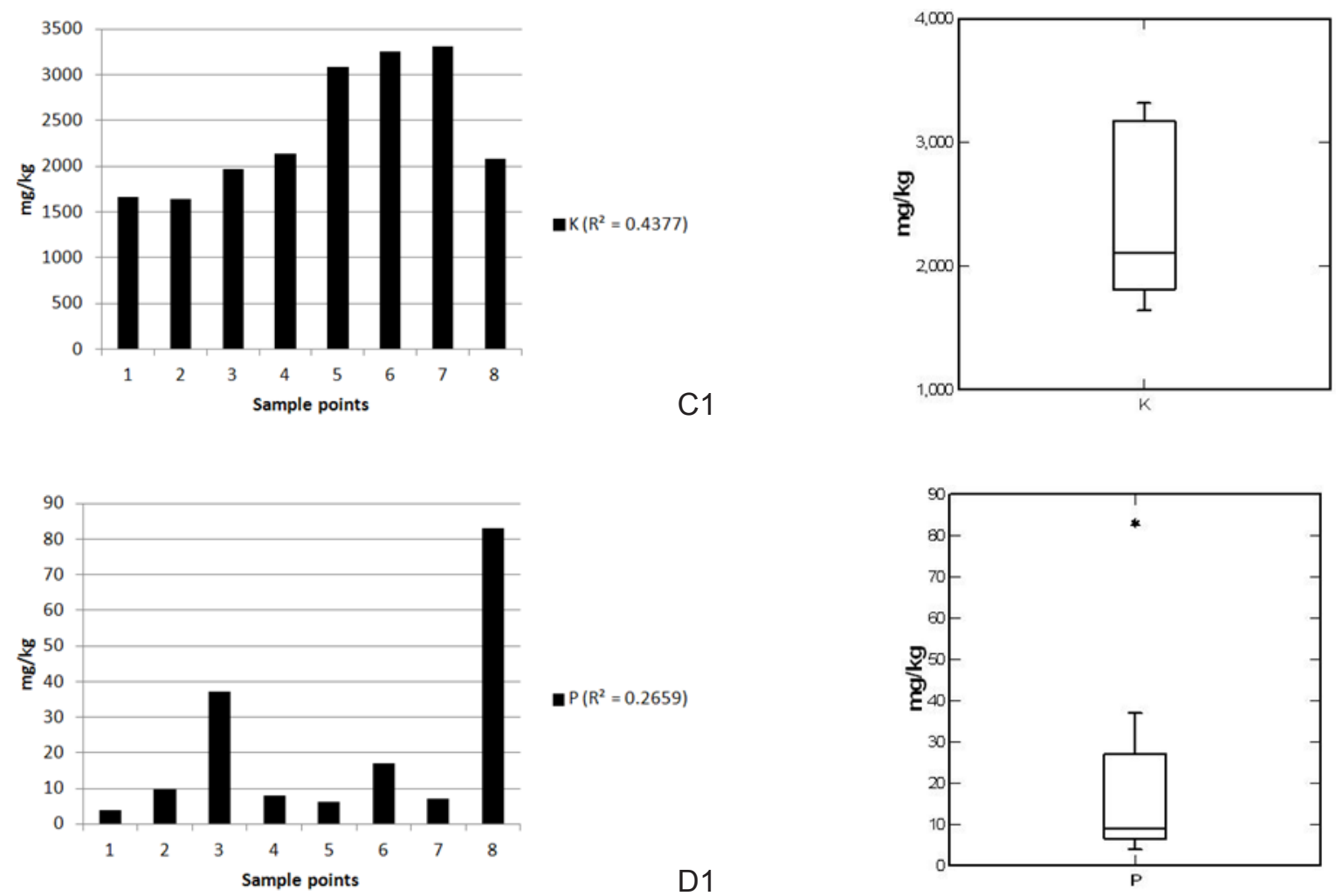

- $P\left(R^{2}=0.2659\right)$

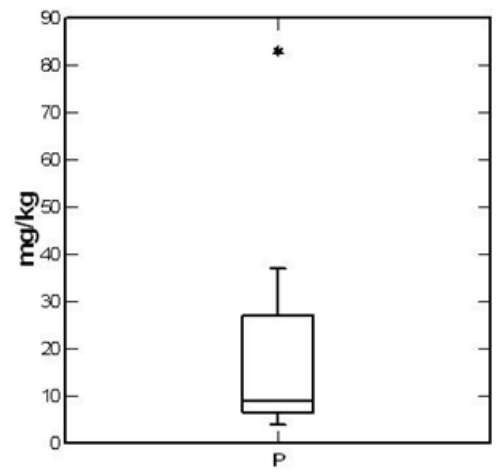

Figure 2 - Parameters analyzed in the soil samples collected in the hypersaline floodplain of the estuary Apodi-Mossoró (Rio Grande do Norte, Brazil), showing the variation in the data between the sites (1) and parameters (2): A1 and A2 - Carbon, organic matter and $\mathrm{Na}^{+2}$; $\mathrm{B} 1$ and $\mathrm{B} 2-\mathrm{Ca}^{+2}$ and $\mathrm{Mg}^{+2} ; \mathrm{C} 1$ and $\mathrm{C} 2-\mathrm{K}^{+} ; \mathrm{D} 1$ and $\mathrm{D} 2-\mathrm{P}$. 

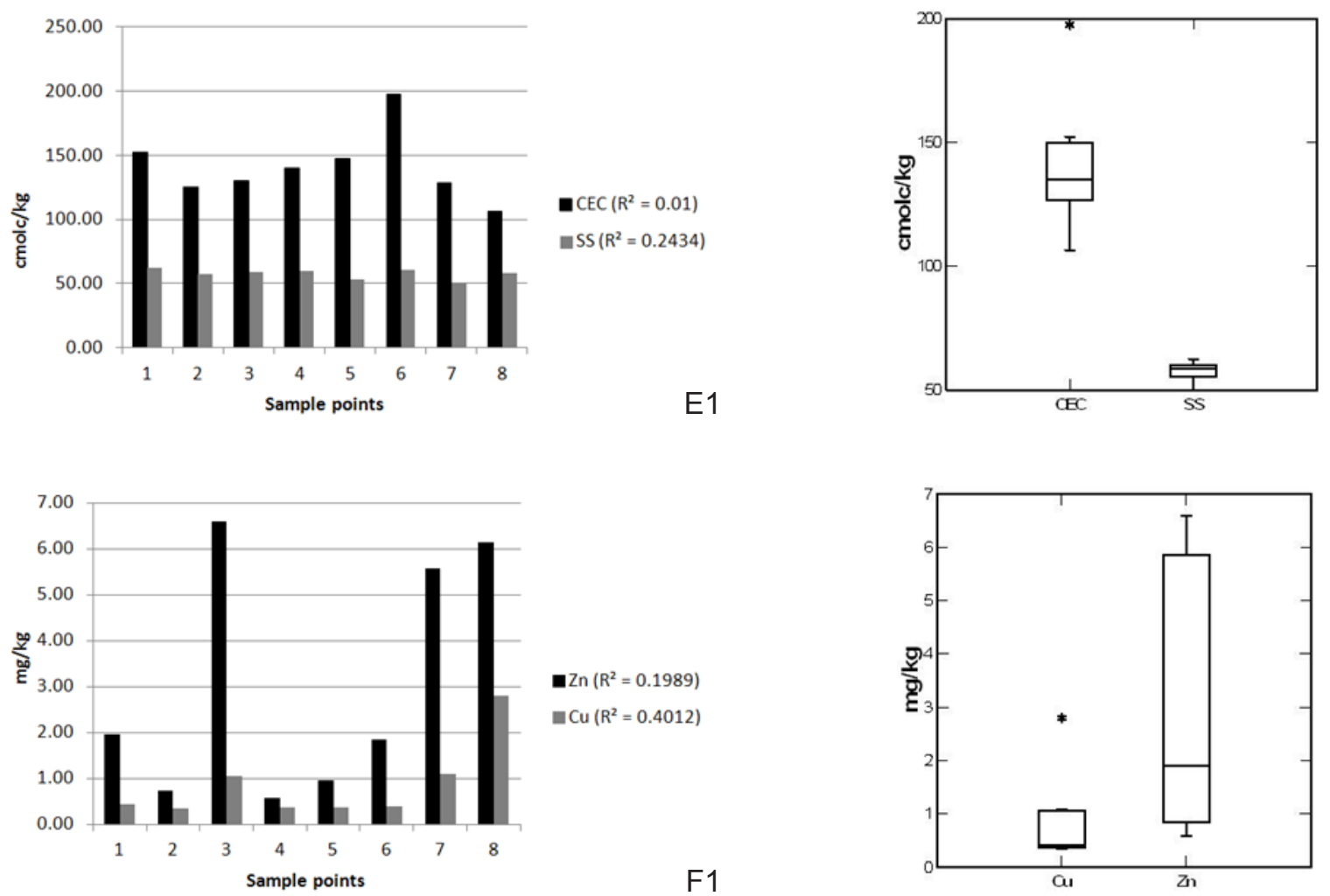

an $\left(R^{2}=0.1989\right)$

a $\mathrm{Cu}\left(\mathrm{R}^{2}=0.4012\right)$

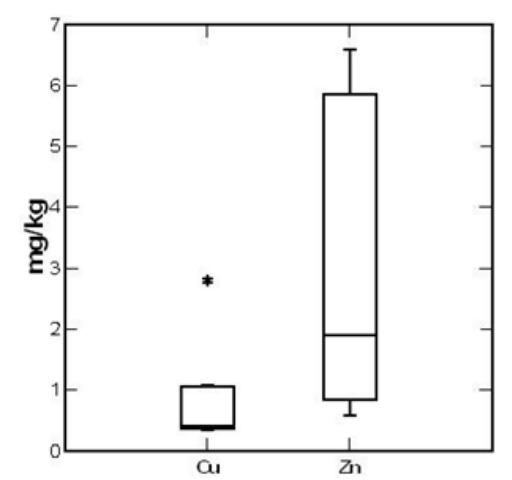

F2

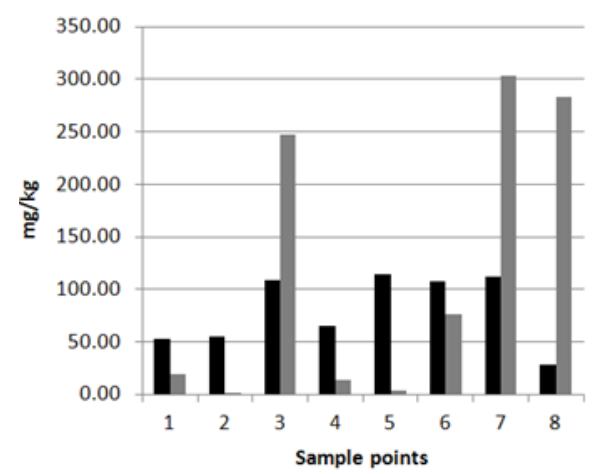

an $\left(\mathrm{R}^{2}=0.0187\right)$

$\mathrm{EFe}\left(\mathrm{R}^{2}=0.3753\right)$
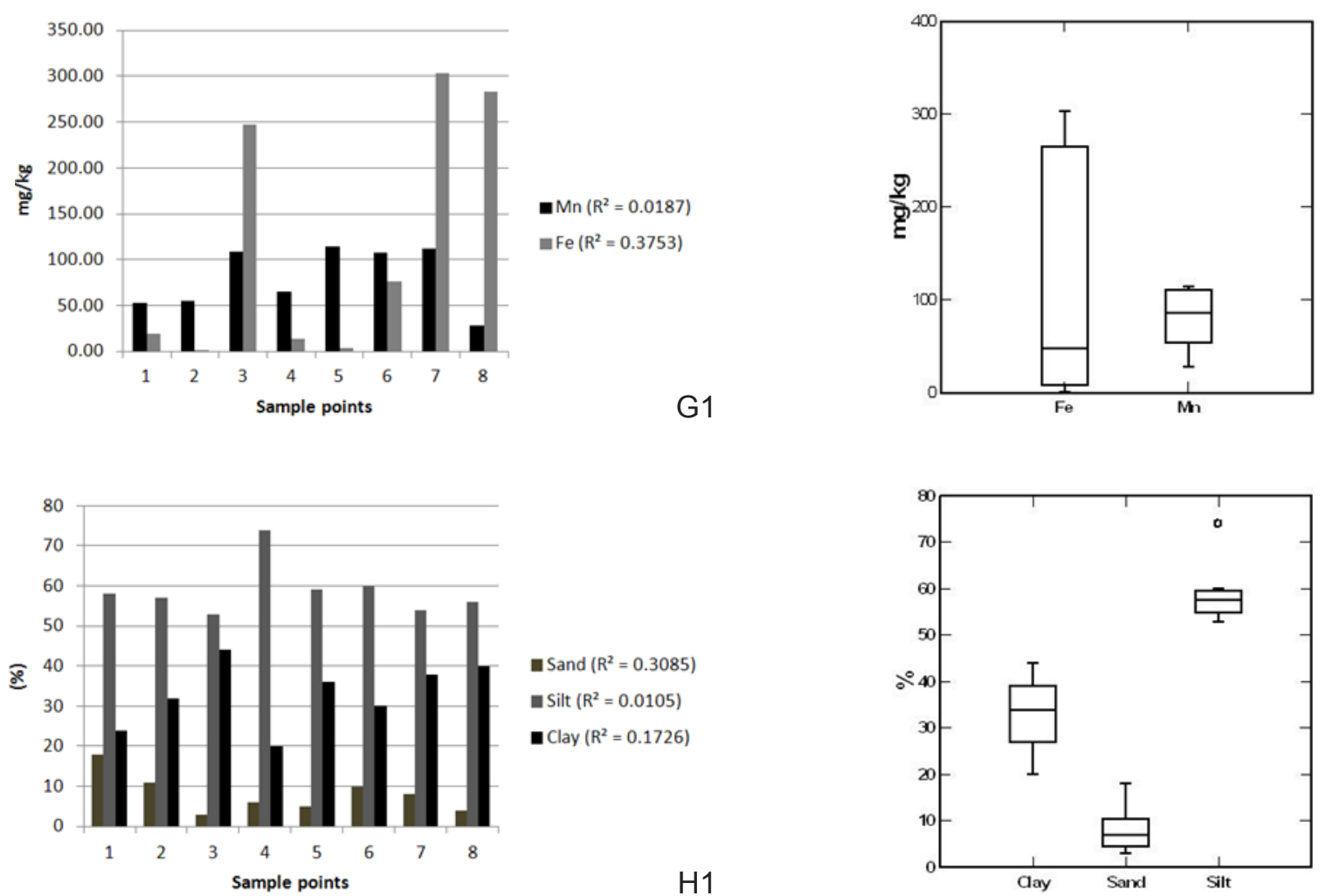

- Sand $\left(R^{2}=0.3085\right)$

n Silt $\left(R^{2}=0.0105\right)$

- Clay $\left(R^{2}=0.1726\right)$

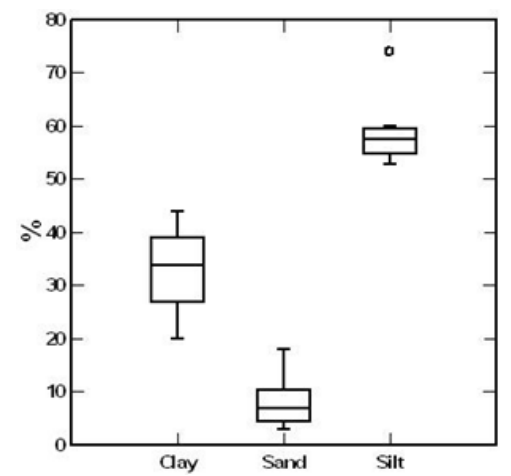

$\mathrm{H} 2$

Figure 2 - (cont.) Parameters analyzed in the soil samples collected in the hypersaline floodplain of the estuary Apodi-Mossoró (Rio Grande do Norte, Brazil), showing the variation in the data between the sites (1) and parameters (2): E1 and E2 - CEC and SNa; F1 and F2 - Zn ${ }^{+2}$ and $\mathrm{Cu}^{+2} ; \mathrm{G} 1$ and $\mathrm{G} 2-\mathrm{Mn}^{+2}$ and $\mathrm{Fe}^{+2} ; \mathrm{H} 1$ and $\mathrm{H} 2-$ Grain size analysis). 
variation was somewhat greater, with values between 77.20 (P8) and 150.00dS/m (P6). This high electric conductivity reflects the high concentration of sodium in the samples, although this parameter had not presented a significant variation between the sampling sites $\left(t_{7}=-12386.90 ; p<0.05 ; R^{2}=0.05\right)$ (Figure 2A), ranging between $16.44(\mathrm{P} 1)$ and $21.93 \mathrm{~g} / \mathrm{kg}(\mathrm{P} 2)$ in the lower estuary, with a progressive reduction from the P6 (27.41 $/ \mathrm{kg})$, P7 (14.80g/kg) and P8 (14.25g/kg).

The concentrations of carbon and organic matter presented a significant variation between the sampling sites $\left(t_{7}=7.6723 ; t_{7}=7.6747 ; p<0.05 ; R^{2}=0.31\right.$, respectively). The carbon concentration varied between 15.32 $(\mathrm{P} 2)$ and $29.38 \mathrm{~g} / \mathrm{kg}(\mathrm{P} 1)$ in the lower estuary, and between 9.76 (P6) and 18.93g/kg (P8) in the upper estuary. In turn, the concentration of organic matter ranged from $26.41(\mathrm{P} 2)$ to $50.64 \mathrm{~g} / \mathrm{kg}(\mathrm{P} 1)$ in the lower
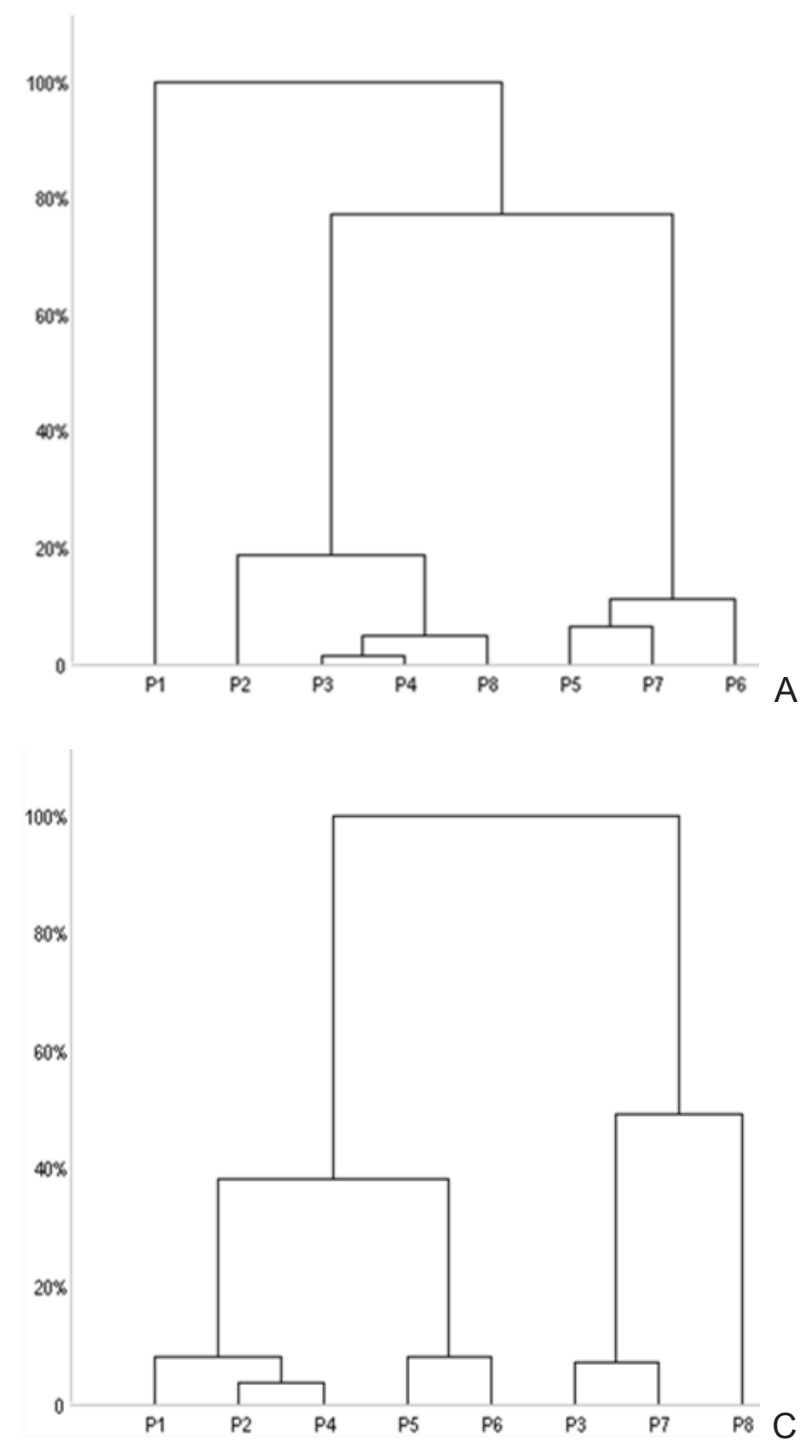

estuary, and from $16.83(\mathrm{P} 6)$ to $32.64 \mathrm{~g} / \mathrm{kg}(\mathrm{P} 8)$ in the upper estuary (Figure 2A).

According to the cluster analysis, these parameters were clearly separated into two estuarine zones, corresponding to the lower and upper course. In the lower course, firstly, the sites P3/P4 were linked, also associated with the P8 and later with the P2. Certainly P8 was included in this group because it is closer to the urban zone of Mossoró town, with higher concentrations of the two analyzed parameters. The second cluster initially associated P5/P7, followed by P6, separating these sites into a group corresponding to another estuarine section (Figure $3 \mathrm{~A}$ ).

Regarding the macronutrients, as well as sodium, the concentrations of calcium and magnesium had no significant variation $\left(\mathrm{t}_{7}=0.0021 ; \mathrm{t}_{7}=0.0019\right.$; $p>0.05 ; R^{2}=0.75$ and 0.42 ) (Figure 2B). For the first,
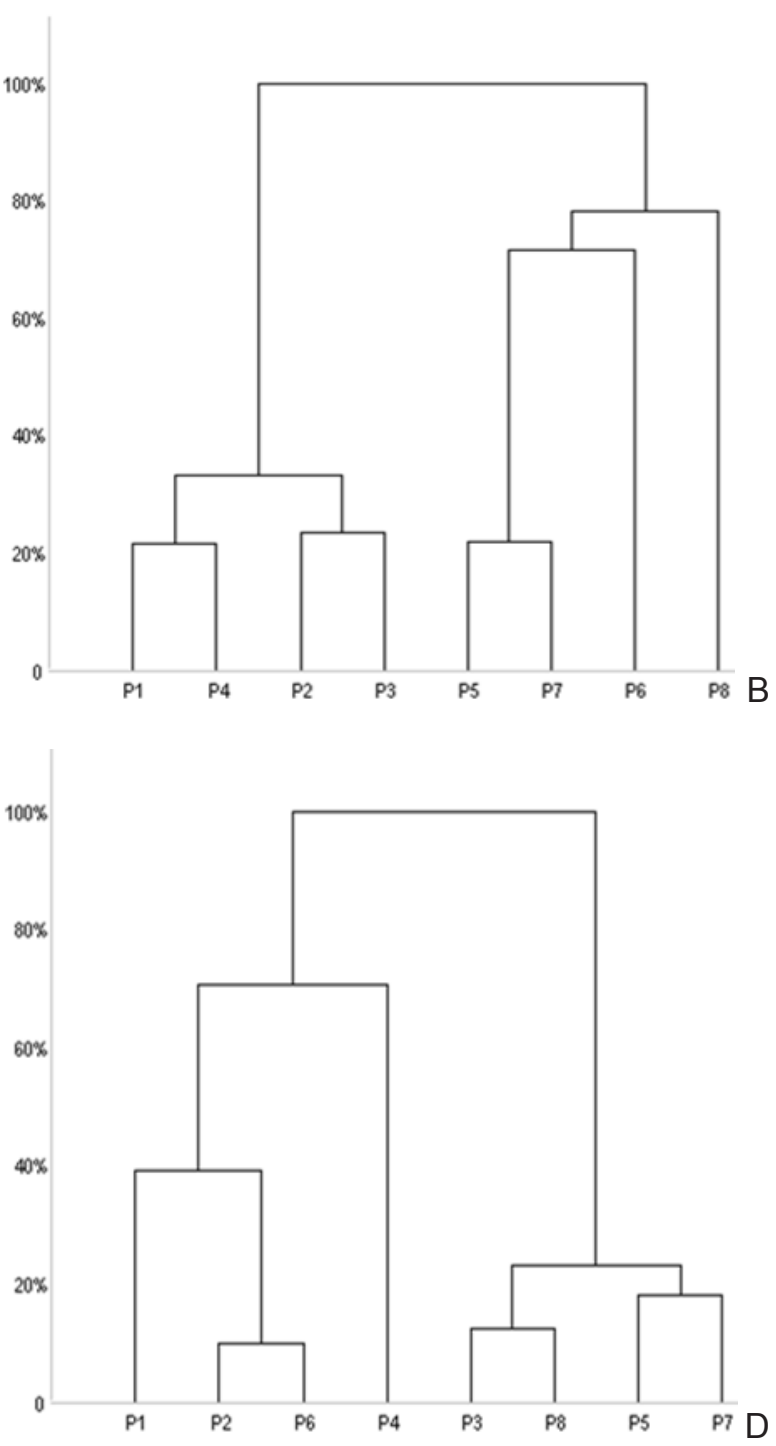

Figure 3 - Dendrograms of the cluster analysis performed with the parameters analyzed in the soil samples collected in the hypersaline floodplain of the estuary Apodi-Mossoró (Rio Grande do Norte, Brazil): A - Carbon and Organic Matter, B - Macronutrients (Na+2, Ca+2, $\mathrm{Mg}+2, \mathrm{~K}+, \mathrm{P}), \mathrm{CEC}$ and $\mathrm{SNa} ; \mathrm{C}-$ Micronutrients $(\mathrm{Zn}+2, \mathrm{Cu}+2, \mathrm{Mn}+2$ and $\mathrm{Fe}+2) ; \mathrm{D}-$ Granulometry. 
the values varied between 21.00 (P2) and $27.25 \mathrm{cmolc} /$ $\mathrm{kg}$ (P3) on the lower estuary, but a gradual decrease was observed on the upper estuary, varying between $21.80 \mathrm{cmolc} / \mathrm{kg}$ (P5 and P6), $18.00 \mathrm{cmolc} / \mathrm{kg}$ (P7) and $8.70 \mathrm{cmolc} / \mathrm{kg}(\mathrm{P} 8)$. Magnesium concentrations ranged from $21.00(\mathrm{P} 2)$ and $27.25 \mathrm{cmolc} / \mathrm{kg}(\mathrm{P} 3)$ in the lower estuary, with a downward trend from the P6 (48.13 $\mathrm{cmolc} / \mathrm{kg})$, P7 $(37.75 \mathrm{cmolc} / \mathrm{kg})$ to P8 $(30.50 \mathrm{cmolc} / \mathrm{kg})$.

As observed for calcium and magnesium, the potassium concentrations had no significant variation $\left(\mathrm{t}_{7}=-7305.4200 ; \mathrm{p}<0.05 ; \mathrm{R}_{2}=0.43\right.$ ) (Figure $2 \mathrm{C}$ ), but high values between $1.64 \mathrm{~g} / \mathrm{kg}(\mathrm{P} 2)$ and $2.13 \mathrm{~g} / \mathrm{kg}(\mathrm{P} 4)$ were observed in the lower estuary, and between $3.31 \mathrm{~g} / \mathrm{kg}$ (P7) and $2.08 \mathrm{~g} / \mathrm{kg}$ (P8) in the upper estuary. In relation to phosphorus, this important nutrient also had no significant variation along the estuary $\left(t_{7}=0.0000 ; p>0.05\right.$; $\left.R^{2}=0.26\right)$ (Figure 2D), with values ranging from $4.0(P 1)$ to $37.0 \mathrm{mg} / \mathrm{kg}$ (P3) in the lower estuary and 6.00 (P5) to $83.00 \mathrm{mg} / \mathrm{kg}(\mathrm{P} 8)$ in the upper estuary.

Finally, analyzing all the cations (Figure 2E), the CEC presented no significant variation $\left(t_{7}=0.0005\right.$; $\left.p>0.05 ; R^{2}=0.01\right)$, with values between $124.91(P 2)$ and $152.35 \mathrm{cmolc} / \mathrm{kg}(\mathrm{P} 1)$ in the lower estuary, and between 106.49 (P8) and $197.54 \mathrm{cmolc} / \mathrm{kg}$ (P6) in the upper estuary. As for the high values of CEC and sodium, a saturation of this element was observed in each sample, which varied significantly $\left(t_{7}=40.4607 ; p<0.05 ; R^{2}=0.24\right)$ (Figure 2E). This variable showed values between 57.25 (P2) and $62.58 \mathrm{cmolc} / \mathrm{kg}(\mathrm{P} 1)$ in the lower estuary, and between 50.05 (P7) and $60.33 \mathrm{cmolc} / \mathrm{kg}$ (P6), in the upper estuary

In relation to the macronutrients $\left(\mathrm{Ca}^{2+}, \mathrm{Mg}^{2+}\right.$, $\left.\mathrm{Na}^{+}, \mathrm{K}^{+}, \mathrm{P}\right), \mathrm{CEC}$ and $\mathrm{SNa}$, the cluster analysis also evidenced a remarkable pattern between the two estuarine zones (upstream and downstream) (Figure 3B), with a first group presenting a strong similarity between the sites P1/P4 and P2/P3, a second group represented by P5/P7, followed by P5/P7/P6 and finally by the sites $\mathrm{P} 5 / \mathrm{P} 7 / \mathrm{P} 6 / \mathrm{P} 8$. Although some differentiation had been found between the two zones, as well as some similarity between the samples collected downstream, on the upper estuary, only the sites P5 and P7 had high similarity, followed by P6 and P8, but still remained pooled in the group of samples taken from this estuarine zone.

Unlike the macronutrients, the concentrations of zinc and copper had a significant variation along the estuary $\left(t_{7}=3.3271 ; t_{7}=2.8556 ; p<0.05 ; R^{2}=0.2\right.$ and 0.40 , respectively), being verified a gradual increase in the concentrations from the P4 (lower estuary) to P8 (upper estuary) (Figure 2F). The values of the first element remained between $0.58(\mathrm{P} 4)$ and $6.59 \mathrm{mg} / \mathrm{kg}$ (P3) in the lower estuary, while in the upper estuary, the values varied between 0.96 (P5) and $6.14 \mathrm{mg} / \mathrm{kg}$ (P8). The copper values ranged from $0.34(\mathrm{P} 2)$ to $1.04 \mathrm{mg} / \mathrm{kg}$ (P3) in the lower estuary and from 0.37 (P5) to 2.80 (P8).
As observed for zinc and copper, the concentrations of manganese and iron presented a significant spatial variation $\left(t_{7}=6.7149 ; t_{7}=2.4772 ; p<0.05 ; R^{2}=0.02\right.$ and 0.37 ) (Figure $2 \mathrm{G}$ ). The manganese varied between $52.60(P 1)$ and $108.75 \mathrm{mg} / \mathrm{kg}$ (P3), in the lower estuary, and between 28.30 (P8) and $114.00 \mathrm{mg} / \mathrm{kg}$ (P5), in the upper estuary. The iron, in turn, presented values between 0.88 (P2) and $247.50 \mathrm{mg} / \mathrm{kg}$ (P3) in the lower estuary, and between 3.44 (P5) and $303.70 \mathrm{mg} / \mathrm{kg}$ (P7) in the upper estuary.

With regard to micronutrients $\mathrm{Mn}^{2+}, \mathrm{Fe}^{2+}, \mathrm{Zn}^{2+}$ and $\mathrm{Cu}^{2+}$ ), the cluster analysis associated the sites $\mathrm{P} 2 /$ $\mathrm{P} 4$ and then P2/P4/P1. The first group connected to the sites P5 and P6, forming thus the low and middle course unit. In relation to these parameters, the site 3 linked with P7, and then with P8 (Figure 3C).

As for the granulometry analysis, the concentrations of sand, silt and clay varied significantly between the sites $\left(t_{7}=4.7068 ; t_{7}=25.3999 ; t_{7}=11.4643 ; p<0.05\right.$; $R^{2}=0.30 ; 0.01 ; 0.17$, respectively), maintaining in every site the proportion silt>clay>sand (Figure $2 \mathrm{H}$ ). The cluster analysis also indicated 2 groups, the first between $\mathrm{P} 2 / \mathrm{P} 6$, followed by P2/P6/P1 and finally P2/P6/P1/P4. The second group was subdivided into P3/P8 and P5/ P7. In a first analysis, the first group represented the upstream stretch of the estuarine zone (P1, P2 and $\mathrm{P} 4)$, whereas indeed, the second group represented the inner stretch of the estuary (P5, P7 e P8), where the inversion between the sites $\mathrm{P} 3$ and $\mathrm{P} 6$ may reflect a particular characteristic of these sites (Figure 3D).

According to the Principal Component Analysis (Figure 4), all these parameters were summarized in a first axis with $39.20 \%$, and a second with $33.64 \%$

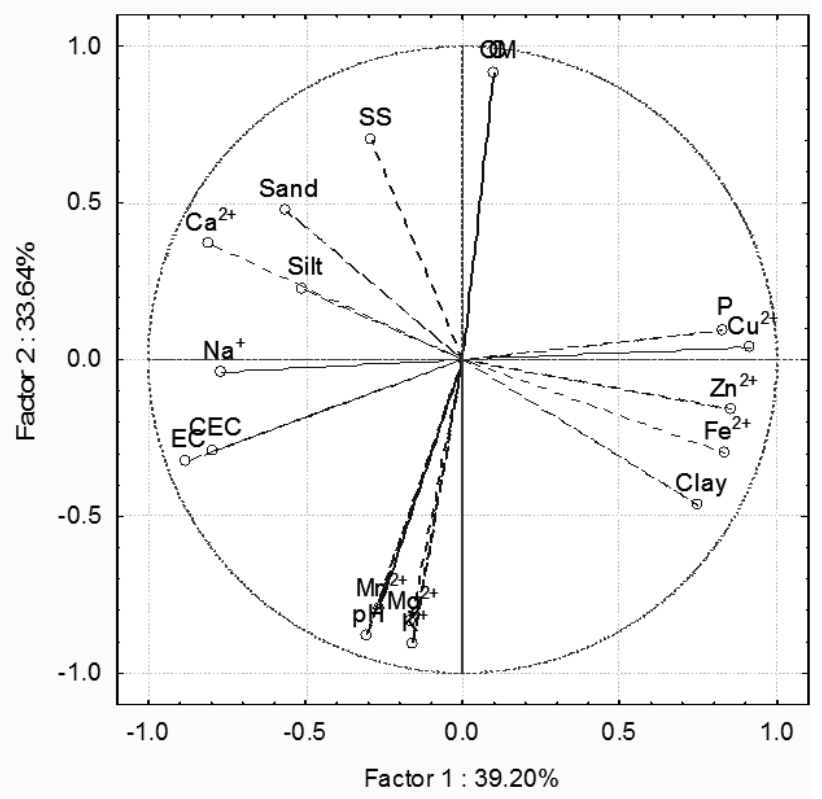

Figure 4 - Principal Component Analysis performed with the parameters determined in the soil samples collected in the hypersaline floodplain of the estuary Apodi-Mossoró (Rio Grande do Norte, Brazil). 
$(p<0.05)$. On the first axis, a positive relationship was registered between the first group composed of $\mathrm{P}, \mathrm{Cu}^{2+}$, $\mathrm{Zn}^{2+}$ and clay vs. the groups formed by $\mathrm{Ca}^{2+}$, silt and sand, and formed by $\mathrm{Na}^{+}$, EC and CEC. The second axis selected positively the carbon and organic matter, along with sodium saturation, indicating a negative relationship with the group formed by $\mathrm{Mn}^{2+}, \mathrm{Mg}^{2+}, \mathrm{K}^{+}$ and $\mathrm{pH}$.

\section{DISCUSSION}

The high concentration of sodium found in the samples is typical of halomorphic soils, derived from intense evaporation in these semi-arid regions, which promote the accumulation of salts in the sediment (Kendall \& Harwood, 1996), where the soil can reach temperatures above $40^{\circ} \mathrm{C}$ (Mendes et al., 2008). All the samples presented high concentration of salts, with surface crusts of crystallized salts (mainly $\mathrm{NaCl}$ ). This feature is typical of soils from these hypersaline plains (shabkhas) (Al-Farraj, 2005), where the tide variations in the estuaries may result in an important specific location of the salinity in the water and soil, where this salinity increase is associated with an increase in the concentrations of the major cations $\left(\mathrm{Na}^{+}, \mathrm{K}^{+}, \mathrm{Ca}^{2+}\right.$ and $\mathrm{Mg}^{2+}$ ) (Schreiber, 1986; Ridd \& Stieglitz, 2002; Du Laing et al., 2009).

In relation to the human influence on the estuary, the P8 exhibited a result of this activity with the highest level of phosphorus $(83.0 \mathrm{mg} / \mathrm{kg}-21$-fold higher than the lowest level found at P1 $-4.0 \mathrm{mg} / \mathrm{kg}$ ). This high phosphorus concentration along with the lowest values of conductivity, sodium and CEC $(77.20 \mathrm{dS} / \mathrm{m}$, $14.25 \mathrm{~g} / \mathrm{kg}, 106.49 \mathrm{cmolc} / \mathrm{kg}$, respectively) may reflect the influence of freshwater input, rich in this nutrient, from the drainage of a zone with intense agriculture and followed by an urban zone (Mossoró City) without effective treatment of domestic sewage.

Higher levels of carbon and organic matter were observed in the mouth of the estuary, and at the last upstream site. A gradual increase in these two variables were verified towards the mouth of the estuary, coinciding with the sector with greatest development of mangrove vegetation (Costa, 2010), although relevant concentrations have been recorded in all samples, as reported by Margesin and Schinner (2001).

Towards upstream of the estuary there was an increase in CEC, determined by the high values of exchangeable cations $\left(\mathrm{Na}^{+}, \mathrm{K}^{+}, \mathrm{Ca}^{+2}\right.$ and $\left.\mathrm{Mg}^{+2}\right)$. As for nutrients, the chemical analyses enabled to verify a gradual increase in their concentrations, towards upstream. In this way, the samples gathered in the upper estuary were characterized by the accumulation of greater levels of the chemical elements analyzed, with increasing values towards upstream. In general, the concentrations of nutrients in the soils examined followed a different order in relation to the estuarine zone where they were collected. In the lower estuary, it was observed the following descending order: $\mathrm{Na}^{+}>\mathrm{K}^{+}>\mathrm{Mn}^{+2}>\mathrm{Fe}^{+2}>\mathrm{P}>\mathrm{Zn}^{+2}>\mathrm{Cu}^{+2}>\mathrm{Ca}^{+2}>\mathrm{Mg}^{+2}$, whereas in the upper estuary, the sequence was altered in the levels of $\mathrm{Fe}^{+2}$ and $\mathrm{Mn}^{+2}$ and in $\mathrm{Mg}^{+2}$ and $\mathrm{Ca}^{+2}$ : $\mathrm{Na}^{+}>\mathrm{K}^{+}>\mathrm{Fe}^{+2}>\mathrm{Mn}^{+2}>\mathrm{P}>\mathrm{Zn}^{+2}>\mathrm{Cu}^{+2}>\mathrm{Mg}^{+2}>\mathrm{Ca}^{+2}$.

The granulometric distribution along the banks of the estuary is heterogeneous, with predominance of silt, with a downward trend of the inorganic fraction concentration: silt > clay > sand. The highest concentration of sandy sediments was observed at site P1, close to the mouth of the estuary, possibly due to the beach dynamics, being this zone directly submitted to the tidal action. The high textural variability may be because the soils are located over zones subjected to both marine (spring tides) and fluvial (annual) floods. These soils are derived from diverse alluvial sediments, and have great heterogeneity in relation to their morphological, physical, chemical, and mineralogical characteristics (Du Laing et al., 2009). By lying close to the coast and present only small areas with halophyte vegetation during most of the year, the finest soil particles are probably subjected to wind transport.

The cluster and PCA analyses applied to the set of sampled sites enabled to identify two zones typical of the estuarine plain, as well as the major groups of parameters related, being one with the greater direct influence of tides (lower estuary) and another, upstream. The samples from the upper estuary presented higher levels of $\mathrm{Zn}^{2+}, \mathrm{Cu}^{2+}, \mathrm{Fe}^{2+}$ and $\mathrm{Mn}^{2+}$ than those from the lower estuary, with intermediate values. In both cases, these concentration values result from a gradual accumulation in the soil (mainly the sodium), after the flood period in the spring tides, followed by a rapid water evaporation caused by high temperatures $\left(>30^{\circ} \mathrm{C}\right)$ and constant winds, where this process of salt saturation typical of soil in floodplains had already been noted along the years in several studies (Schreiber, 1986; Jolly et al., 1993; Ridd \& Stieglitz, 2002; Al-Farraj, 2005; Mees \& Singer, 2006; Dendooven et al., 2010).

\section{CONCLUSION}

The Multivariate statistics applied to the dataset showed the possibility to evidence from geochemical studies that the same hypersaline unit presents variations in the analyzed parameters. Through the cluster analysis it was possible to differentiate 02 sectors with distinct characteristics (lower and upper estuary), where the highest salt concentrations (clearly reported by EC, CEC and SNa) were obtained from a large zone of accumulation in the upper course of the estuary, and 
sites with intermediate concentrations, close to the coast. Certainly these results were related to factors such as the higher tidal influence (close to the coast), geographical position along the estuary, input of human origin (the case of the phosphorus), etc.

Regarding the levels, the geochemical analyses pointed out that the samples are typically from an environment under a natural process of salinization, and characteristically, as a function of the estuarine tidal dynamics and of the semi-arid climate, not suggesting inland sources of these metals to the area. Although the literature had reported contributions from urban runoff for some stretches of this region, it was remarkable that the high values found derive from natural and gradual saturation through sea water evaporation that remains accumulated, where the external contributions to the estuary are little expressive. These data can be compared with other areas that keep this halomorphism characteristic, and possibly can distinguish human sources for some elements recorded at high concentrations.

\section{ACKNOWLEDGEMENTS}

We would like to thank the personnel of LABESA (Laboratory of Semi-arid Ecology) and EMPARN (Empresa de Pesquisa Agropecuária do Rio Grande do Norte) for field and lab assistance. First author would like to thank to Coordenação de Aperfeiçoamento de Pessoal de Nível Superior (CAPES), for the research fellowship granted (BEX. Process $n^{\circ}$ 5834104). We also would like to thank the anonymous reviewers for their very constructive comments and suggestions, which substantially improved the quality of the paper.

\section{REFERENCES}

Abílio, G.S.; Cupelo, A.C.G. \& Rezende, C.E. 2004. Metal distribution in sediments of an offshore exploration area Santos basin Brazil. 4th International Symposium of Environmental Geochemistry in Tropical Countries, Brazil, Armação dos Búzios. 320-321 pp.

Al-Farraj, A. 2005. An evolutionary model for sabkha development on the north coast of the UAE. J. Arid Environ. 63: 740-755.

Álvarez-Rogel, J.; Carrasco, L.; Marína, C.M. \& Martínez-Sánchez, J.J. 2007. Soils of a dune coastal salt marsh system in relation to groundwater level, micro-topography and vegetation under a semiarid Mediterranean climate in SE Spain. Catena 69(2): 111-121.
Ayres, M.; Ayres, J.M.; Ayres, D.L. \& Santos, A.S. 1988. BioEstast. Versao 1.0. Sociedade Civil Mamirauá, MCT - CNPq, Belém, Pará, Brasil.

Curtis, R.; Evans, G.; Kinsman, D.J.J. \& Shearman, D.J. 1963. Association of dolomite and anhydrite in the recent sediments of the Persian Gulf. Nature 197: 6779-6800.

Dendooven, L.; Alcántara-Hernández, R.J.; ValenzuelaEncinas, C.; Luna-Guido, M.; Perez-Guevara, F. \& Marsch, R. 2010. Dynamics of carbon and nitrogen in an extreme alkaline saline soil: A review. Soil Biol. Biochem. 42(6): 865-877.

Du Laing, G.; Rinklebe, J.; Vandecasteele, B.; Meers, E. \& Tack, F.M.G. 2009. Trace metal behaviour in estuarine and riverine floodplain soils and sediments: a review. Sci. Total Environ. 407(13): 3972-3985.

Duke, N.C.; Ball, M.C. \& Ellison, J.C. 1998. Factors influencing in mangroves biodiversity and distributional gradients. Global Ecol. Biogeogr. Let. 7: 27-47.

EMBRAPA. 1997. Manual of methods for soil analysis. 2 ed. Centro Nacional de Pesquisa de Solo/ EMBRAPA, Rio de Janeiro, $212 \mathrm{p}$.

EMPRESA BRASILEIRA DE PESQUISA AGROPECUÁRIA-EMBRAPA. 1999. Brazilian System of Soil Classification. Centro Nacional de Pesquisa de Solos/EMBRAPA, Rio de Janeiro, 286.

FAO - Food and Agriculture Organization of ONU. 2006. World reference base for soil resources. Report 103. World Soil Resources, Rome.

Gallego, J.L.R.; Ordonez, A. \& Loredo, J. 2002. Investigation of trace element source from an industrialized area (Avilés northern Spain) using multivariate statistical methods. Environ. Internat. 27: 589-596.

Hardle, W. \& Simar, L. 2007. Applied Multivariate Statistical Analysis. 2 ed. Springer, Berlin, 455p.

Kendall, A.C. \& Harwood, G.M. 1996. Marine evaporites: arid shorelines and basins. In: Reading, H.G. (ed.). Sedimentary environments: processes, facies and stratigraphy. Blackwell, Oxford. 281$324 \mathrm{pp}$.

Kendall, A.C. 1984. Evaporites. In: Walker, R.G. (ed.) Facies Models. 2 ed. Geoscience Canada, Reprint Series 1, Canada. 259-296 pp.

Lovelock, C.E.; Ball, M.C.; Martin, K.C. \& Feller, I.C. 2009. Nutrient enrichment increases mortality of mangroves. PLoS ONE 4(5): e5600.

Margesin, R. \& Schinner, F. 2001. Biodegradation and bioremediation of hydrocarbons in extreme environments. Appl. Microbiol. Biotechnol. 56:650-663. 
Mees, F. \& Singer, A. 2006. Surface crusts on soils/ sediments of the southern Aral Sea basin, Uzbekistan. Geoderma 136(1-2): 152-159.

Mendes, A.M.S.; Fontes, R.L.F. \& Oliveira, M. 2008. Variabilidade espacial da textura de dois solos do Deserto Salino, no Estado do Rio Grande do Norte. Rev. Ciên. Agron. 39(1): 19-27.

Moreira, E.G.S.; Demattê, J.L.I. \& Marconi, A. 1989. Caracterização e gênese de Solonetz solodizado do sertão central e do médio Jaguaribe - Estado do Ceará. An. ESALQ 46(2): 319-341.

Ridd, P.V. \& Stieglitz, T. 2002. Dry season salinity changes in arid estuaries fringed by mangroves and saltflats. Est. Coast. Shelf Sci. 54: 1039-1049.

Schreiber, B.C. 1986. Arid shorelines and evaporites. In: Reading, H.G. (ed.) Sedimentary environments and facies. 2 ed. Blackwell Scientific Publishers, Oxford. 189-228 pp.

Silva, A.M.A.; Barbosa, J.E.L.; Medeiros, P.R.; De Medeiros Rocha, R.; Lucena Filho, M.A. \& Costa, D.F.S. 2009. Zooplankton (Cladocera and Rotifera) variations along a horizontal salinity gradient and during two seasons (dry and rainy) in a tropical inverse estuary (Northeast Brazil). Pan-Am. J. Aq. Sci. 4 (2): 226-238.

Silva, M.A.M.; Schreiber, B. \& Santos, C.L. 2000. Evaporites as mineral resources. Rev. Bras. Geof. 18(3): 338-350.

Vita, S.; Luna, F.J. \& Teixeira, S. 2007. Early chemistry techniques as described in the chronicles written by travelling naturalists who explored colonial and imperial Brazil. Quim. Nova 30(5), 1381-1386.

Zhang, T.; Zeng, S.L.; Gao, Y.; Ouyang, Z.T.; Li, B.; Fang, C.M. \& Zhao, B. 2011. Assessing impact of land uses on land salinization in the Yellow River Delta, China using an integrated and spatial statistical model. Land Use Policy 28(4): 857-866.

Submetido: Outubro/2012 Revisado: Novembro/2013 Aceito: Dezembro/2013 